\title{
CLIMATE CHANGE ADAPTATION: USE AND VALUE OF A CLIMATE BUFFER AREA
}

\author{
F. BAL ${ }^{1} \&$ J.M. VLEUGEL ${ }^{2}$ \\ ${ }^{1}$ RISSK, Haarlem, The Netherlands. \\ ${ }^{2}$ Delft University of Technology, The Netherlands.
}

\begin{abstract}
Most climate researchers agree that the changing world climate may irrevocably threaten life on our planet. It is no coincidence that water is involved in climate change, because the earth surface and atmosphere largely consist of water in different physical states and dimensions. Climate change becomes visible in less predictable and more severe weather conditions, like excessive rainfall and wind. These show up with a higher frequency and intensity, even in areas that never before experienced them. Seasonal patterns may fade or deepen and become more irregular. More sustainable human behaviour may on paper reduce the pace of or even reverse climate change. Widespread lack of such behaviour by a growing world population consciously replicating western-style consumerism makes it unlikely that real progress occurs in the foreseeable future. Comparable to an area like transport, only technical solutions may help to relieve the pressure. Water management has been used to allow humans to live safely on land for thousands of years. Many of the current water management systems are not up to the task anymore. Flooding of villages and cities is a growing global problem. Replacing out-dated systems is time consuming and very expensive, while political will seems hard to mobilize. But, if frequency and intensity of precipitation will stay at a higher level in future, cautious action is needed to prevent disasters. This paper will discuss a Dutch plan for a multifunctional area that would allow management of excessive water volumes. Adding a water retention area leads to higher investment costs, but benefits like enhanced protection may outweigh these higher costs. Given the unknown future risk and cost of flooding, damage costs may be much higher than assumed. From a no-regret perspective, it is wise to carry out projects, which currently have a (slightly) negative benefit-cost ratio.
\end{abstract}

Keywords: buffering, climate change, economic valuation, rainfall.

\section{INTRODUCTION}

It is commonly expected by scientists that precipitation extremes will increase as the climate warms [1]. Regardless if rain falls in large quantities in a short period of time or in more modest, yet continuous quantities over a longer period of time, there will be an impact on man and nature. The situation becomes more complex if alternating periods of flooding and drought hit the same area. Both high and low levels of water may weaken flood defences like dykes. In affected areas, road and rail infrastructures and sewage systems are also targeted. Flooding may threaten natural habitats, pollute water and land, cause damage to properties and put human life at risk.

Areas may sometimes be affected for a longer period of time. Reverting to the old situation may take a long time and large investments. In case of extensive damage, it may even be illusory to turn back the clock. In ancient days, accepting the new situation was very common. If conditions became unbearable, migration started and areas became abandoned. Factors such as a growing world population, increasing urbanization [2] and sunk costs largely prevent man from abandoning areas in our era, however.

Technical water management is very effective under normal circumstances, but excessive precipitation compromises its capabilities. Yet, building for occasions (still) perceived as being of the once in a lifetime category is often regarded as too expensive. Costs have to be born by the tax payers, who do not always benefit (directly) from such schemes. This, and 
factors like land ownership, use of space (with alternative uses), intrusion of the landscape and equity issues influence decisions regarding need, size/design and location of such facilities. Then, only excessive damage may trigger a policy response. The Atlantic hurricane Katrina caused extensive flooding in the southern USA from Florida to Texas in 2005. In the USA, damage cost reached a record high of US\$ 108 billion. Surge protection failed, in particular, the levees in metropolitan New Orleans, built after 1965. The wind moved 8.5-m high water masses up the Mississippi river, causing 53 levee breaches. Eighty percent of the city was flooded, with water-mud levels up to $5.5 \mathrm{~m}$, killing 1833 people and making 370,000 homeless. It finally gave way to a new flood protection scheme for the southern portion of Louisiana. With a cost of US\$ 8 billion, the costs are actually moderate [3].

\section{THE SYSTEM AND THE PROBLEM}

This paper will focus on a 'natural' solution to deal with extreme precipitation in one of the most densely populated countries in the world. Nature itself has various ways to deal with (excess amounts of) water. Water can be absorbed by the soil and its vegetation or stored in basins like lakes. It can evaporate or freeze. It can also run off to other areas and finally into a sea. Natural buffering capacities have a certain 'saturation' point, however.

Nature can fulfil these functions on its own, but humans can also adapt existing nature areas to temporarily allow additional water storage. River water and run-off from conventional farm land usually contains (excessive amounts) nutrients and chemicals like pesticides. A precondition when using a nature area for water buffering should be that this does not ecologically degrade the nature area or water quality [4]. To protect the nature areas of highvalue, an alternative is to design new nature or mixed-use (multifunctional) 'buffer areas' in rural or urban areas, which (partially) act as water retention areas.

This paper will focus on key functions of retention areas and does not discuss fine technical or ecological details as this is outside the research scope of the authors. The following research questions will be elaborated:

- What functions could (should) a new buffer area offer?

- What are the costs and benefits of developing this buffer area?

- Is the buffer area as a concept applicable in other, comparable, situations?

\section{A BUFFER AREA FOR WATER MANAGEMENT}

To protect built-up areas, several strategies can be deployed:

- Partitioning. Secondary defences may split a large area into several compartments and thereby reduce the risk that a large area is flooded completely after primary defences fail. Objects with the highest economic or social-historic value may be in such dual protected zones, while lesser valued object may only receive a single-layer of protection [5].

- Flooding areas. Aquatic buffer zones, also known as conservation buffers or riparian zones, are of strips of vegetated land that can be used to protect more valuable stretches of land [6].

- (Climate) buffers. They can be divided into retention/detention (regular situations) and incident management areas (exceptional situations) [7,8]. Nature or multifunctional areas can be used for this purpose.

- Flood-resistant building. This strategy has been used for millennia all over the world. Buildings can be built on hills. A recent development is the use of floating platforms. 
In practice, several strategies may be combined, depending on the prevailing conditions. The result is a varying balance between land and water mass.

\subsection{Damage prevention or mitigation by climate buffers}

Canals and basins are sufficient to regulate water levels. In times of flooding, buffer areas allow water to move less restrained. Water levels will vary more than before, but not enough to prevent people to live and work normally; otherwise abandoning the area may be preferable. Small fluctuations require a relatively large buffer area or else only a limited amount of water can be stored. Where water is allowed to regular flood areas, (temporal) wetlands may develop, starting with vegetation such as helophytes. Wetlands have four main functions [9]:

1. Regulation - Run-off and flood prevention; water catchment and groundwater recharge; storage and recycling of organic matter, nutrients and human waste, biodiversity.

2. Carrier - Space, cultivation.

3. Production - Water, fuel and energy.

4. Information - Aesthetic and historic; cultural and artistic inspiration.

\subsection{The challenge for the Netherlands}

The Netherlands is among the richest (GDP/capita) and most densely populated (inhabitants/ square $\mathrm{km}$ ) countries in the world. Water has been an economic blessing and a curse in its long history. Thirty percent of the country lies well below the level of the shallow, yet treacherous North Sea and this may become $60 \%$ in the next centuries due to climate change. Very high seawater levels threaten life not only along the shores but also in inland areas, as the normal release of excess river water may (temporarily) come to a halt.

The country is located in the delta of the major canalized European rivers Rhine and Maas. Extensive, still continuing, investments in water defence have strongly reduced flooding risk since the major flooding of the southern provinces of Zeeland and North-Brabant in the infamous year 1953. Flooding like in the United Kingdom, Middle- and Eastern Europe has not happened since, but experts warn for more water from upstream countries like Switzerland, Germany and Belgium.

Rainfall increased by $14 \%$ in the past century and a further increase is expected in the Netherlands [10]. With more and irregular rainfall, river water levels are likely to fluctuate more. Higher water levels may mean that water is passing with increased speed and in more destructive force. In dry periods, lower water levels may create cracks in defences, which may cause them to fail once water levels rise again.

Additional protection helps to manage future risk and size of flooding in the Netherlands [11]. Inland water is usually sweet water, but there is the threat of infiltration by salt/brackish ground water if not enough sweet water is available, in particular in low-lying areas. This is detrimental for farming - the Netherlands is among the world's largest producers and exporters of agricultural products. Another infiltration issue is eutrophication via unleashing minerals from the riverbed, farm land or inlets.

\subsection{The Westflank - a plan for a new park-city}

The provinces of North- and South-Holland made a plan to urbanize an 'in-between' area in the Haarlemmermeer polder by expanding existing living areas by 10.000 new houses, water 


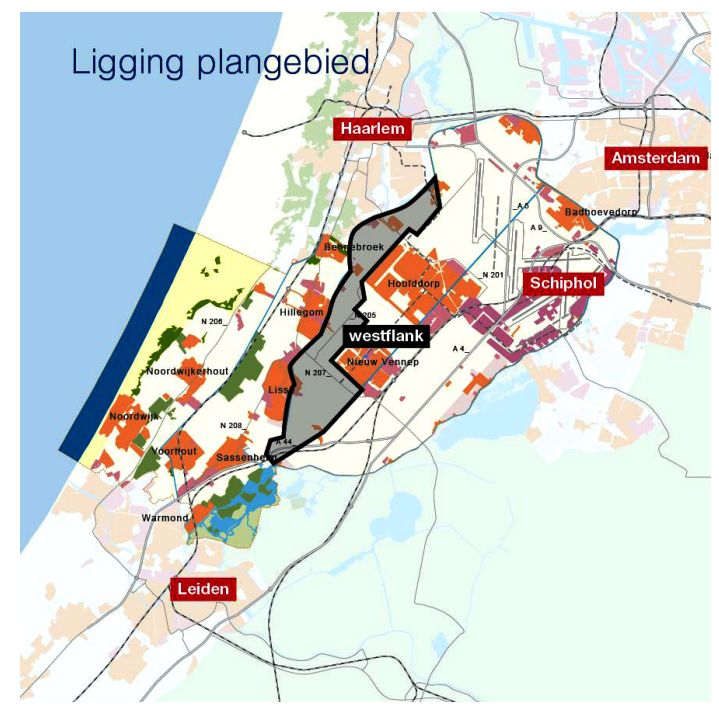

Figure 1: Impression and location of the Westflank plan area.

Source: [13].

buffers, green recreational/nature areas, restructuring and expansion of provincial roads and a high-quality public bus system. Integrating these functions means that the smallest amount of space is needed. The plan sketched in Figs 1-3 would allow people to live close to or partially on the water. A few centuries ago, this polder and, in particular, the area of the airport was a rather treacherous inland sea; 'Schiphol' translates like 'an area where ships were doomed'. The plan tackles two major issues; a regional deficit of 30,000 houses [12] and a lack of space to temporarily store excess (river) water. To give an idea about distances, Schiphol airport is about $15 \mathrm{~km}$ east.

\subsubsection{Housing demand and use of space}

Demographic changes increase the demand for new houses; a growing population, a smaller average household size, more single person households and a partially outdated housing stock. Part of these houses would be for staff of foreign companies. Higher management is in particular attracted by high-quality living areas. The plan has a 70:30\% split between up-market/owned and socially rented houses. Actual split may differ according to market conditions, however.

A paradox in Dutch spatial planning is that part of the country is used very intensively for non-agricultural activities, while in the remainder agricultural monoculture can be found; $2 \%$ of the population is farmer, yet they still own around 50\% of the land. The Haarlemmermeer polder is an example of wrong spatial planning. Compared with airports serving a similar or higher number of passengers, Schiphol uses space very inefficiently, having 2-3 times the number of runways and other facilities. There are restricted use areas, both on the ground and in the air. Its noise contour includes cities like Amsterdam, Leyden and Haarlem. The airport is a magnet for office and logistic activities, regardless if they are economically related with it. Regional roads dissect the polder. There are recreational areas, but the (provincial) government wants additional ones, in particular multifunctional areas with nature. 
10.000 (70\% up-market) houses (existing: 56.000)

1124 ha (2776 acres) of recreational/nature area [692 ha wet nature, 332 ha green areas, 124 ha water] A lake of $2 \mathrm{mln} . \mathrm{m} 3\left(2.6159 \mathrm{e}+6 \mathrm{yd}^{3}\right)$ for seasonal storage Widened waterways: $1 \mathrm{mln} . \mathrm{m} 3\left(1.3080 \mathrm{e}+6 \mathrm{yd}^{3}\right)$ of peak storage Total storage: 250 ha (617 acres)

Figure 2: Key data of the Westflank plan. Source: [14].

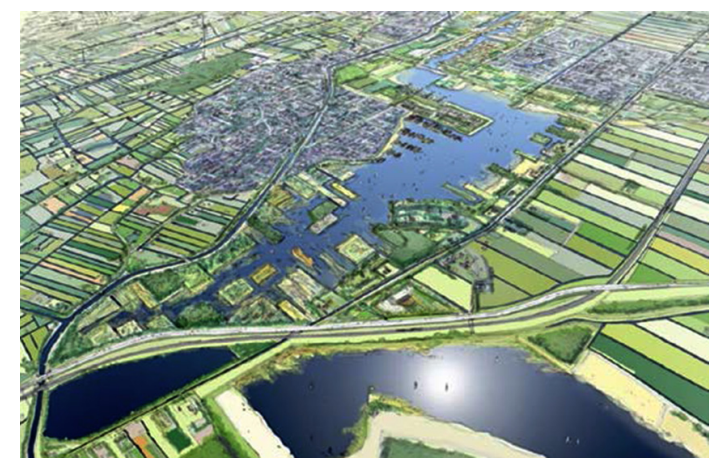

Figure 3: Possible layout of the Westflank.

Source: [14].

\subsubsection{Sustainable water management}

The nation-wide introduction of sustainable water management assumes a need to (periodically) store large amounts of river water. Water agency Hoogheemraadschap Rijnland has an advanced pumping system in the Haarlemmermeer polder. Expanding this system is regarded as inappropriate. Pumping has a very local impact and may only help temporarily. Water retention is an interesting alternative. It could take place at the surface or underground (not in the scope).

The plan has no or only sustainable farming. Contrary to traditional farming, where most of the water is flushed to adjacent areas swiftly in order to keep a water level convenient for farming (but too low for (wet) nature), the polder retains most of the water in future.

To answer research question 1 , this water storage is one of the means to protect surrounding houses against flooding. A size of 3 million $\mathrm{m}^{3}$ may seem impressive on paper. The location close to houses reduces allowable fluctuations to $50-100 \mathrm{~cm}$. This reduces emergency storage capacity. This means that more of these areas are necessary. The water and green areas provide local and regional recreation opportunities, which add economic value to the plan.

The Westflank plan will now be analysed in a social cost-benefit analysis (SCBA).

\section{A SOCIAL COST-BENEFIT ANALYSIS}

\subsection{Introduction}

Economists use SCBA to estimate the net welfare gain or loss (benefits minus costs) of a public investment plan for society at large. SCBA tells how efficient this result can be 
achieved. It does not deal with the necessity or the welfare impact (distribution of winners and losers and possible compensation of 'losers' by 'winners'), nor does it say if the estimated result warrants subsidization if costs are higher than benefits; equity issues are the domain of politicians. What remains is a decision-making and communication tool [15].

SCBA is a commonly used tool, which has benefitted from standardization in the past decades. This means that methodologically, SCBA studies are comparable and provided data access; they may also be replicated by others, both of which are important scientific requirements. Unfortunately, SCBA still has major flaws, which negatively affect project assessment. In case of nature, the first issue is the incomplete understanding of the functioning of ecosystems. Second, there is a valuation problem. The public good character of nature makes it difficult to value the benefits of (new) nature; there is no market (price) for most of the 'products' of nature areas. These gaps in the green data set stimulate a bias in SCBA; its human-centredness. This means that in most valuation studies, nature is primarily valued through the human eye, focusing on benefits to mankind. Environmental economists (have to) rely on partial analysis and ad hoc expert judgements. These issues do not allow them to calculate the full economic value of nature areas. As a result, supporters of nature projects are in a weaker position than supporters of non-nature projects.

\subsection{Competing investment opportunities}

Policy units, such as CPB, the main economic advisory unit of the Ministry of Economic Affairs in the Netherlands, use a conservative approach. CPB treats investments in nature largely as costs instead of investments in area development [16]. It compares 'hard' investment costs with 'uncertain or non-monetizable' benefits, which are labelled as 'to be advised' (TBA). In SCBA, TBA's translate as zero; hence, nature projects will have a negative balance. Alternative investment opportunities, in particular roads, have no or a smaller number of TBA's, which makes it easier to calculate a positive balance. In transport economics, the value of time is used to monetize user benefits of (infrastructure) plans. A plan will pass if there are net user benefits - computed as a reduction in travelling time multiplied by the value of time per travel motive, such as business or leisure travelling. It can be a strategy to 'manage' the data, for instance, the value of travel time. It helps that data can vary significantly in practice depending on the assumptions and the available data [17]. A plan will also be more acceptable if its implementation costs are lower(ed). Cost underestimation is not uncommon in engineering, either because of lack of data (in case of new technologies or applications) or intentionally (to pass a cost assessment). When the first drill crushes the soil, the project 'suddenly' becomes much more expensive, because of the real cost surface. More infrastructure initially means more traffic capacity, which reduces travelling time; hence, more people will use the infrastructure. With sufficient growth in demand, the additional capacity is used and the problem returns but now at (much) higher traffic volumes. In the short term, the higher traffic volume will already create more congestion in non-expanded sections of the network. The actual economic benefit of additional infrastructure is grossly overrated, especially in an already dense network (see also [18]).

\subsection{Nature makes a plan more expensive?}

Consultancies like CPB are frequently asked to compare a plan with a reference (base case or other plan). Adding a nature area to a plan increases investment costs. It is of little surprise to see that nature scores low or negative in terms of benefits in such assessments. Public 
decision-makers and lobbyists respond to such outcomes by questioning the green elements of a plan. There can be a thin line between 'more expensive' and 'too expensive' (and unnecessary) in public decision-making. A plan may even be trimmed until green is just a marketing phrase.

It may go too far to say that if a plan contains nature elements, then the traditional costbenefit approach is invalid, but it certainly requires adaptation.

\subsection{Two SCBA approaches}

A sizeable investment could be made in this project. We will compare the conventional (Table 1) and an alternative approach (Table 2), where nature is a long-term investment. In both cases, a model was used to estimate relevant parameter values and calculate project results. Discussing these models is not part of the scope. Data will be presented, and the outcomes compared.

Table 1: SCBA of the Westflank plan (million Euros).

\section{Cost}

1. Public investments

2. Lost income from farming

3. Management and maintenance of green areas

4. Public space in housing areas

5. Total costs/investments

Financial-economic benefits

6. Land sale (for housing, excl. VAT)

7. Consumer surplus (social housing)

8. VAT compensation

Subtotal benefits housing

Financial-economic cost/benefit

External impact of infrastructure

9. Savings from flood prevention

10. Water quality

11. Air quality

12. Better living quality existing houses

13. Recreation

14. Nature and biodiversity

15. Attractive for foreign companies

16. Travel time savings

Total external benefits

Cost-benefit deficit

\section{8}

76

24

253

826

615

16

$-^{\mathrm{a}}$

631

$-195^{\mathrm{b}}$

3

TBA

TBA

1

$3.3+$ TBA

TBA

TBA

Cannot be calculated

$20.2+$ TBA

$-177^{c}+$ TBA

Source: [16].

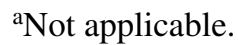

${ }^{\mathrm{b}}$ Derived value, not officially calculated.

'Rounded off.

${ }^{\mathrm{d}}$ The rate of discount was $5.5 \%$, as commonly used in The Netherlands. 


\subsubsection{The conventional approach}

The most subjective part of any analysis is the treatment of data. As discussed earlier, this has a major influence on the final result of the analysis. In the CPB analysis, the project is compared with reference projects, which have a lower spatial quality, due to a lack of water and green areas. The costs and benefits of these areas are then calculated via a difference analysis to have the net benefit of nature. The value of nature is part of the external impact of infrastructure. The scope is limited and the many TBA's reduce the monetary value. The analysis is also rather partial. In Table 1 for instance, lost income from farming is mentioned (2), but the benefit of removing modern farming, one of the main forces behind the destruction of ecosystems world-wide, is hardly mentioned. The estimated savings from flood protection (9) are unrealistically low compared with a study by a Dutch hydrological expert [19] or foreign damage estimates such as [20]. If the 10,000 new houses are included in the calculation, damage costs may rise by 1.2 billion. or on average 85 million Euro per case (break of a dam). Existing Dutch hydrological models strongly underestimate the risks, because they were developed using historic data. Climate issues were not an issue, then. The real damage is likely to be much higher, both direct - restoration - and indirect - closure of businesses. Flooding scenarios are missing. Insurance companies do not cover flood damage, nor does the government. Most of the benefit of the plan accrues to consumers (7 and 12). The benefit for business is unknown (15). A major issue is also the lack of distinction between incidental and yearly costs and benefits. SCBA is supposed to assess investments, yet the conventional investment analysis practice is only partially followed.

\subsubsection{An alternative approach}

Here, the project is analysed by combining SCBA with a total cost of ownership (TCO) framework, where a full life-cycle is considered. A life-cycle has three phases: (a) acquisition and realization; (b) operations; (c) decommissioning (optional). In a conventional SCBA, the distinction between (a) and (b) is not always made, while (c) is non-existent. This makes the conventional approach less transparent and incomplete. If different stakeholders are involved in each phase of a project, restricted transparency creates equity issues (not in the scope of this paper). The alternative approach is thus far superior. Phase three (decommissioning) is added to make the TCO complete. For a living area, this is usually not done, but for a business facility, like a plant, adding this phase could be useful. The cost of decommissioning is a major determinant of the amortization period of the investment. In this example, a period of 18.56 years is enough to break-even (IRR $=4 \%$ ). If the project would not be decommissioned, then the payback time would be only 7.1 years. If we take the average life of a house, 50-70 years, then these payback periods are highly interesting.

The aim was to extract as much of the cost and benefit data as possible from available sources. As a result, a much higher level of detail could be achieved. The scope is a bit wider.

Benefits of nature were partially derived via a benefit transfer of values from comparable Dutch multifunctional reference sites. Benefit transfer is used when it is impossible or too expensive to carry out a completely new valuation study. Benefit transfer is 'most reliable when the original site and the study site are very similar in terms of factors such as quality, location, and population characteristics; when the environmental change is very similar for the two sites; and when the original valuation study was carefully conducted and used sound valuation techniques'. [21] Precautions were taken to insure a real comparison with reference projects.

The benefit of water protection is still small. It may be a strong underestimation, depending on how flooding occurs and whether the Haarlemmermeer is split into different compartments 
(which it is not now). The actual overall benefit from the plan may be higher, keeping in mind that revenue from entry tickets sold (if applicable); tax revenues (housing, tourists), rent from social housing, facilities etc., revenue from parking facilities, from events and small-scale farming are not included. Due to lack of specific data, these are left out of the analysis, making the net project result a conservative estimate. Despite removing many of the TBA's, additional TBA's were added. This is a normal outcome when one opens a black box.

\subsubsection{A comparison}

To answer research question 2 , the costs and benefits of this plan have been made tangible. In the conventional SCBA (here represented by [16]), the project will have a substantial deficit and its authors advise against the project. Our alternative approach has a different outcome, because we were able to show that they largely underestimate key benefits of the plan. The investment in nature pays itself back in a relatively short period of time. For an investment analyst, the cash flow curve follows a classical pattern: in the first phase, costs are larger than benefits (net cash outflow); in the second (operations) phase, a surplus will be realized (net cash inflow), followed by a net cash outflow in the third phase (decommissioning).

\subsection{Status of the plan}

The national government influenced the plan in different ways. It supported the local municipality in the study and planning process. To remove the deficit (cf. [16]), it also promised a subsidy of 48 million Euros. At the same time, the same national government decided that a new $380 \mathrm{kV}$ aerial power line should be built straight through the planned location. An earlier suggested that eastern path for this power line was rejected because of flight safety concerns as this would be close to Schiphol Amsterdam airport. Such a power line requires strict spatial zoning, because of health concerns. This would reduce the plan to an unprofitable size. Consequently, the province of North Holland stopped its work on the plan. Without such support, the local government has stalled the project.

Since the housing market in The Netherlands went into a crises with prices dropping on average by $20 \%$ between 2008 and 2013, and just recently shows first signs of recovery [22], it is rather unlikely that the project will be realized (in the intended way). There are also competing plans (Park 21, etc.) for the same region. The project shows a serious lack of coordination (or even competition) between the different layers of governments, which is rather common in this country.

\section{EVALUATION}

To add a water buffer area to an urban development scheme is still rare. Compared with the past, where policy followed a disaster, this is a forward looking approach. It is partially experimental, as we do not know the real dangers luring in front of us and for sure such a project costs more than a project without such an area. The future benefits may be realized, in particular if precipitation becomes (much) worse and irregular in future.

SCBA is a useful tool to assess the net benefit of an investment project for society. It allows comparison of the project with one of more alternative investment opportunities. Nature projects or projects containing a nature element could in principle be compared with projects not having any nature or green element in them, provided that certain conditions are met. In particular, care should be taken to compare monetary units with one another. It does not make much sense to compare 'to be advised' (TBA) values with 'hard' values, because TBA 


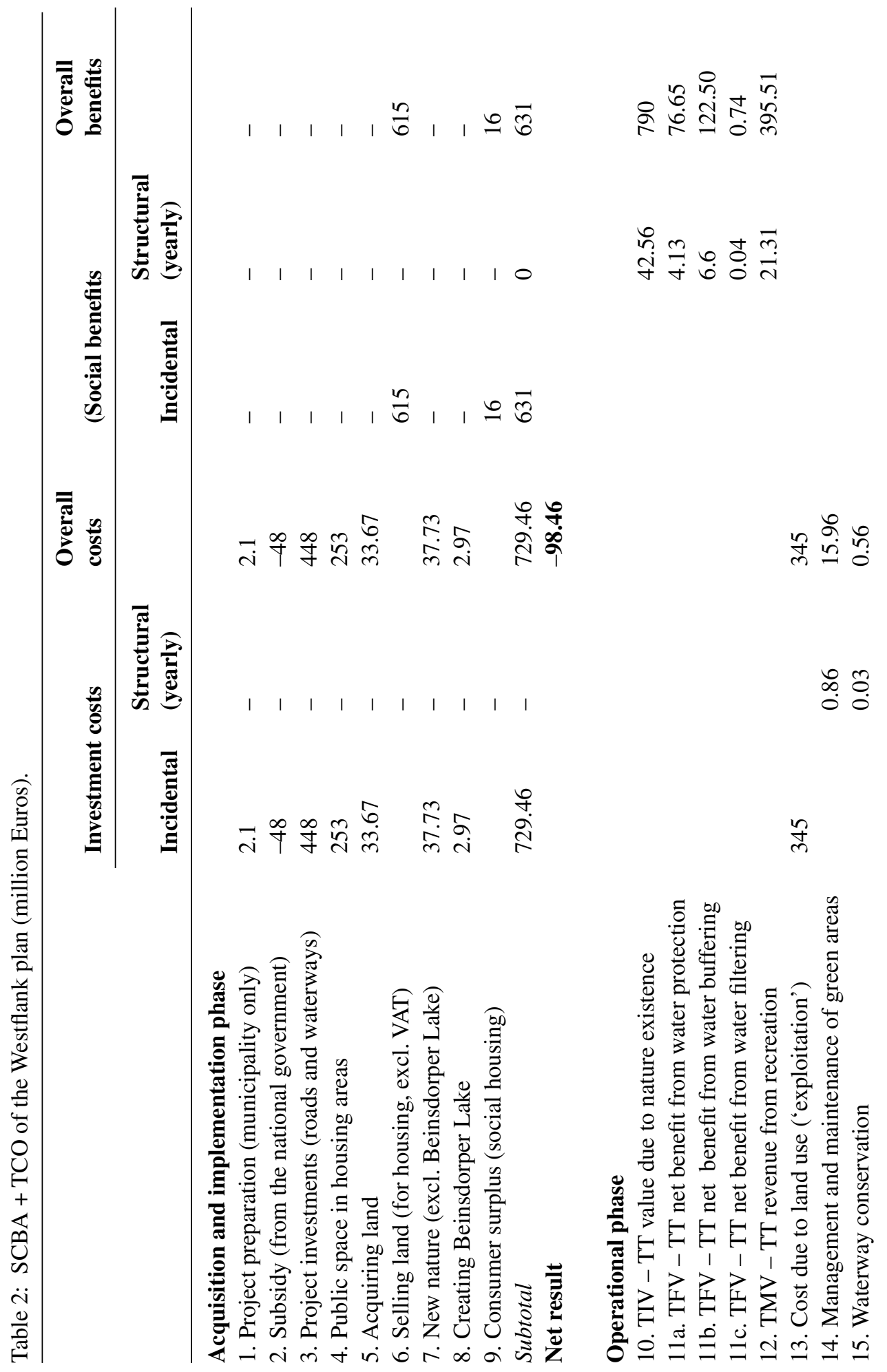




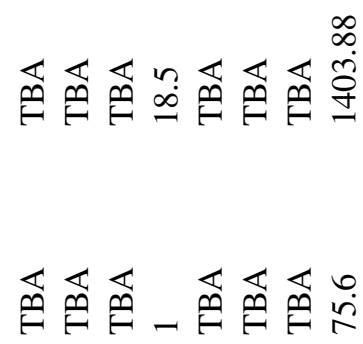

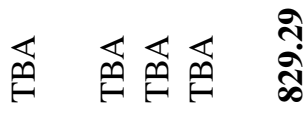

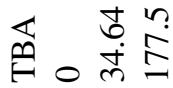

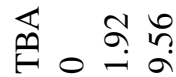

点

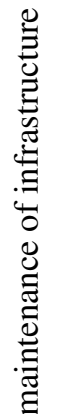

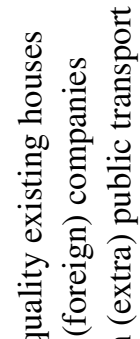

司

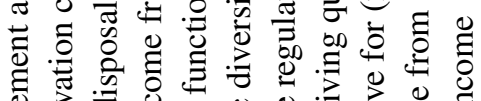

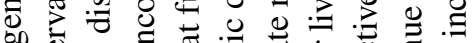

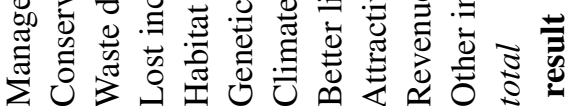

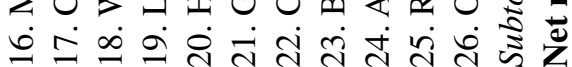

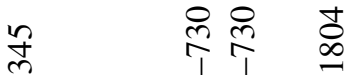

-

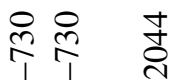

$\hat{m} \quad 00 \quad \hat{n}$

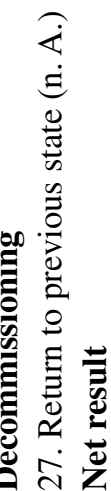

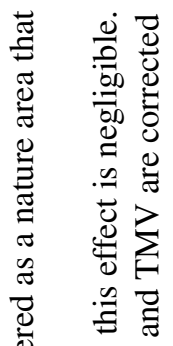

蔍壱

究

$\Xi \pm$

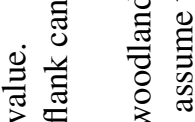

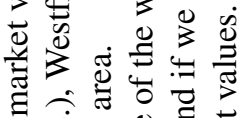

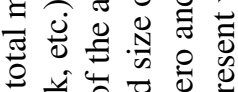

11 过 0

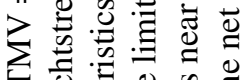

记

थे

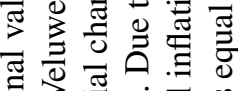

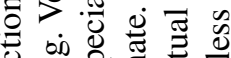

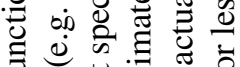

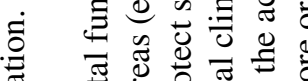

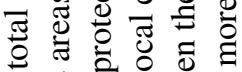

II

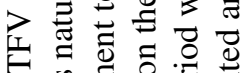

杄

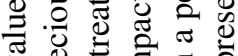

$\stackrel{0}{\supset} \Xi \Xi \Xi$

폴 Ð

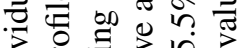

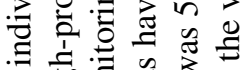

完.

도원

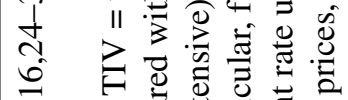

.

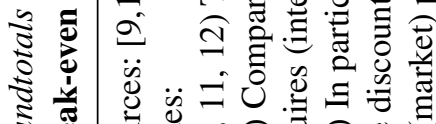

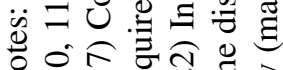


translates to zero in calculations. To reduce the number of TBA's, it is necessary to devote (more) time and money to the collection of 'green' data, as there is a serious lack of such (standardized) data. Ecologists and economists tend to work separately, which makes it harder to find common ground and to understand each others' needs [23]. More communication between these groups should, therefore, be stimulated. Next, more research budget is needed to collect (and standardize) 'green' data. The same approach has been followed successfully in the assessment of infrastructure projects, like roads and railways.

To answer research question 3, the concept of a buffer area inside an urban area is applicable in situations of similar size and application area (buffering, anti-flooding, filtration, recreation).

Finally, there is a need for independent assessment of such projects. In many cases, either a government agency or a consultancy company paid by the government carries out SCBA. In both cases, there is a considerable chance that the outcome is biased, in particular, if the green data set remains as incomplete as it is currently.

\section{CONCLUSIONS AND RECOMMENDATIONS}

The paper started with three research questions:

- What functions could (should) a new buffer area offer?

- What are the costs and benefits of developing this buffer area?

- Is the buffer area as a concept applicable in other, comparable, situations?

A buffer area could offer protection against excessive (temporary) volumes of water. Next to that, the buffer area could provide water filtration. If combined with an urban area, then the buffer area may provide opportunities for recreation, in particular if it has green or nature areas. Combining these functions is rather new and provides options for cross-subsidization. Given the size of the plan area, more of such areas are necessary to protect the Netherlands from flooding. This is already happening, although the pace is slow, as there is much resistance from the land-owners, in particular traditional farmers. This highly subsidized and privileged power factor in society does not care too much about anything but its own business.

Cost and benefit estimations are surrounded by uncertainty. Adding a buffer area (nature) to a plan increases not only costs but also benefits. Government studies, such as the earlier mentioned CPB study [14], are likely to strongly underestimate the cost of flooding. They also find it difficult to deal with the benefits of a buffer area, in particular with the nature component. In our alternative approach, we have discovered many flaws in their approach. Based on that, we may assume that a SCBA of the plan is positive, implicating that the planned Westflank area would be a sensible investment if carried out in the initial form (without the power line). In our opinion, the buffer area concept is applicable in other, comparable situations.

\section{REFERENCES}

[1] Lenderink, G. \& Meijgaard, E. van, Linking Changes in Hourly Precipitation Extremes to the Clausius-Clapeyron Relation, KNMI: Utrecht, 2010. http://www.knmi.nl/cms/ content/90945/linking changes in hourly precipitation extremes_to_the_clausius-clapeyron_relation.

[2] Kante, B., Local capacities for global agendas. impact of cities on the global environment, UNEP Conference, Barcelona, 15 September 2004. 
[3] Wikipedia. Hurricane Katrina. https://en.wikipedia.org/wiki/Hurricane_Katrina. A 150 km dyke may cost up to US\$ 8 bln. Technisch Weekblad, 24, p. 3, 2013.

[4] IF Technology and partners, Waterberging in de diepte. Hoofdrapport: Arnhem, 2005.

[5] Keizer, A.J., Leidraad voor beperking overstromingsschade na doorbraak regionale waterkeringen, MSc thesis, Technical University Twente, 2008.

[6] City of Edmonton, California, USA. http://www.edmonton.ca/environmental/documents/Background_Report Wetland Buffer_ER_Dedication_Guidelines.pdf.

[7] WorldPress.com. The twentyten blog. Sustainable Stormwater Management, available at http://sustainablestormwater.org/ 2009/05/28/stormwater-101-detention-andretention-basins.

[8] Communications Bureau de Lynx, Wageningen, The Netherlands, Klimaatbuffers in Nederland, available at http://klimaatbuffers.nl/projects/peat-areas.

[9] Bos, E.J., \& Bergh, J.C.J.M. van den, Economic Evaluation, Land/Water Use, and Sustainable Nature, Conservation of "De Vechtstreek" Wetlands, Research Memorandum 98036, Free University, Amsterdam, 1998.

[10] Reijnders, L., Klimaatverandering en regenval, 2007, available at www.kennislink.nl.

[11] WL|Delft Hydraulics, Overstromingsrisico's in Nederland in een veranderend klimaat, Delft, 2007.

[12] Provincie Noord-Holland, Monitor Woningbouw 2010, Provincie Noord-Holland: Haarlem, 2011.

[13] LPBL, MKBA in duurzame gebiedsontwikkeling, Duurzaam waarderen en verzilveren, LPBL: Amsterdam, 2010.

[14] Projectgroep Haarlemmermeer-Bollenstreek, Gebiedsuitwerking HaarlemmermeerBollenstreek - Resultaat Projectenveloppen, Haarlem, 2005.

[15] See reference [13].

[16] CPB, Beoordeling Westflank Haarlemmermeer, Notitie voor het Ministerie voor Milieu en Ruimtelijke Ordening, CPB: Den Haag, 2010.

[17] Berg, M. van den, De maatschappelijke kosten-baten analyse (MKBA) van evaluatieinstrument naar sturingsinstrument bij natuurprojecten, MSc thesis, ASRE-MSRE, Amsterdam, 2011.

[18] Oregon Department of Transportation, The value of travel-time: estimates of the hourly value of time for vehicles in Oregon 2005, Salem, OR, 2006. See also Colman, R., Full cost accounting of highways: infrastructure deficit accounting in highway investment analysis, GPI Atlantic, 1998.

[19] See reference 5.

[20] Floods could cost Germany 12 billion euros in economic damage, warns Fitch. Available at http://finance.yahoo.com/news/ floods-could-cost-germany-12-162855215.html

[21] King, D.M. \& Mazzotta, M., Benefit Transfer Method, available at http://www.ecosystemvaluation.org/benefit_transfer.htm.

[22] Neisingh, P. \& Stokman, A., What drives consumer confidence in times of financial crises? Evidence for The Netherlands, DNB Working Paper No. 394, September 2013.

[23] Bal., F. \& Vleugel, J.M., Improving environmental assessment: methodological considerations and practical solutions, Environmental Impact 2012, eds. C.A. Brebbia \& T-S. Chon, WIT Transactions on Ecology and the Environment 162, WIT Press: Southampton, pp. 65-74, 2012, ISBN 978-1-84564-604-2.

[24] Gaaff, A., Strookman, M. \& Reinhard, S., Kosten en baten van alternatieve inrichtingen van de Horstermeerpolder, Report 4.03.09, LEI, Den Haag, 2003. 
[25] PvdA, Noord-Holland maakt zich zorgen over Westflank, Koninklijke BDU Uitgevers B.V., Barneveld, 2012.

[26] Dijkstra, A., Hendriks, E., Molen, P. van der, Posthoorn, P. \& Rijsdorp, A., Schetsboek Randmeer Noordoostpolder, RIZA Werkdocument 2000.134, Rijksinstituut voor Integraal Zoetwaterbeheer en Afvalwaterbehandeling, Lelystad, 2000.

[27] Mulder, M., Klaassen, M. \& Vreke, J., Economische Graadmeters voor Natuur, DLO Natuurplanburo-onderzoek Werkdocument, 1998/10, DLO, Den Haag, 1998.

[28] Gemeente Haaren, Afvalwegwijzer 2002, Haaren (Noord-Brabant), 2002.

[29] Brouwer, R., Langford, I., Bateman, I., Garrod, G.D. \& Turner, K., A Meta-analysis of Wetland Contingent Valuation Studies, Мimeo, CSERGE, University of East Anglia, Norwich, 1997.

[30] Luijt, J. \& Voskuilen, M.J., Bedrijfsuitkomsten in de Nederlandse particuliere bosbouw over 2010, LEI-rapport 2012-053, LEI Wageningen UR, The Hague, July 2012. 